\title{
Regional Diversification of Electricity Consumption in Rural Areas of Poland
}

\author{
Paweł Siemiński ${ }^{1, *\left(\mathbb{D}, \text { Jakub Hadyński }^{1} \text {, Jarosław Lira }\right.}{ }^{1}$ and Anna Rosa ${ }^{2}$ (D) \\ 1 Department of Economics and Economic Polity in Agribusiness, Poznań University of Life Sciences, Wojska \\ Polskiego 28, 60-637 Poznań, Poland; jakub.hadynski@up.poznan.pl (J.H.); jaroslaw.lira@up.poznan.pl (J.L.) \\ 2 Institute of Rural and Agriculture Development, Polish Academy of Sciences, Nowy Świat 72, \\ 00-330 Warsaw, Poland; arosa@irwirpan.waw.pl \\ * Correspondence: pawel.sieminski@up.poznan.pl
}

Citation: Siemiński, P.; Hadyński, J.;

Lira, J.; Rosa, A. Regional

Diversification of Electricity

Consumption in Rural Areas of

Poland. Energies 2021, 14, 8532.

https://doi.org/10.3390/

en14248532

Academic Editor: Ashish

Prakash Agalgaonkar

Received: 6 October 2021

Accepted: 14 December 2021

Published: 17 December 2021

Publisher's Note: MDPI stays neutral with regard to jurisdictional claims in published maps and institutional affiliations.

Copyright: (c) 2021 by the authors. Licensee MDPI, Basel, Switzerland. This article is an open access article distributed under the terms and conditions of the Creative Commons Attribution (CC BY) license (https:// creativecommons.org/licenses/by/ $4.0 /)$.

\begin{abstract}
Access to energy, including electricity, determines countries' socio-economic development. The growing demand for electricity translates into environmental problems. Energy is therefore a crucial element of the European Union's sustainable development strategy. This article aims to present the changes taking place in the electricity market in Poland considering the goals of the energy policy until 2040. This is the basis for the determination of the scale of processes taking place in the Polish energy sector from two perspectives, i.e., the production of electricity considering its level and energy carriers used, and the consumption of electricity in households depending on their location (rural vs. urban areas). The research was conducted at the regional level (NUTS 2 until 2017) in Poland. Secondary data from the Central Statistical Office (GUS) contained in the Local Data Bank were used, along with information from the European Commission and Eurostat websites. Results of the study made it possible to identify areas in which a greater environmental load is observed due to increasing electricity consumption. The coefficient of localization and concentration (by Florence) and the rate of change were applied. These results indicate that, in Poland, it is now the rural areas that have a greater negative environmental impact than urban areas, resulting from differences in unit energy consumption. Compared to the other provinces, rural areas of Podlaskie province had the highest rate of growth in energy consumption in the years 2004-2019, with an annual average of almost $20 \%$.
\end{abstract}

Keywords: electricity; production; consumption; rural areas; energy carriers; Poland

\section{Introduction}

Due to development, more and more energy resources are necessary to satisfy social needs as well as production. There is a growth trend in electricity consumption all over the world. Abolhosseini et al. [1] indicate that electricity consumption will constitute an increasing share of global energy demand over the next two decades, contributing to climate change and environmental pollution, and constituting a serious threat to human health. Energy is therefore a crucial element of the European Union's sustainable development strategy.

Climate problems in EU countries are noticeable as issues that may significantly affect or limit future socio-economic development. The cause of climate problems is the increasing emission of greenhouse gases due to anthropogenic activities directly related to the combustion of fossil fuels for electricity, heat, and transport. However, it is primarily the combustion of fossil fuels that causes atmospheric pollutants that are harmful to the environment and human health. Fossil fuels play a dominant role in global energy systems [2]. They are responsible for more than $70 \%$ of world greenhouse gas emissions [3]. In 2019, the largest share of greenhouse gas emissions, $77 \%$, was those related to energy production [4], while, in 2015, this share was 78\% [5]. 
Coal is the most damaging fossil fuel for environmental concerns and carbon emissions. In many countries, it is increasingly being replaced by natural gas for electricity production. However, reserves of coal could last a long time and still play a role in meeting primary energy demand [6]. Poland is rich in energy resources, with hard coal and lignite, i.e., energy resources with a potentially high environmental impact, predominating [7].

The electricity market has a dominant position among other energy markets (heat, car fuel, etc.) in terms of the scale of production.

In the $\mathrm{EU}$, the greatest role is played by the conventional energy sources, while a decrease in production has recently been observed (e.g., in the years 2017-2019 mean annual production was approximately $7 \%$ lower at 1.166 million GWh). Nuclear energy (0.729 GWh in 2019) is the second most important energy source in the EU.

Conventional energy production accounted for $42.8 \%$ of the total, while nuclear power rose to $26.7 \%$ of the total. In the EU countries, a considerable role is also played by wind power $(13 \%)$ and hydro power $(12 \%)$ (Figure 1$)$.

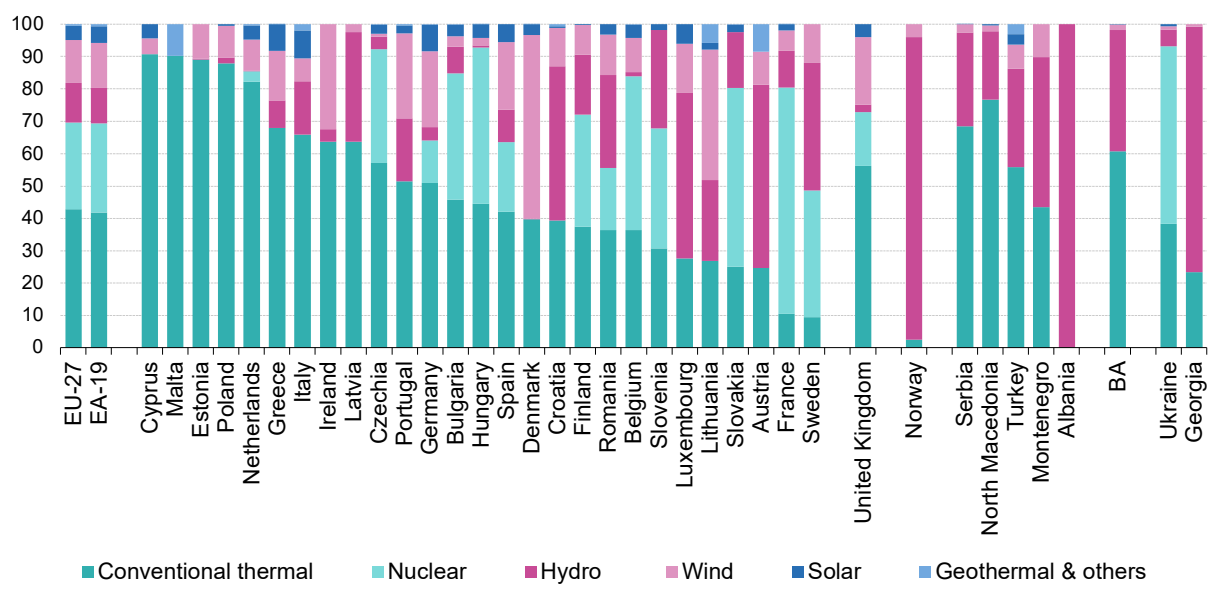

Figure 1. Energy production in the EU countries in 2019 (\%). Source: Eurostat.

In the EU, a significant problem in energy production is related to limited and rapidly depleting energy resources, thus resulting in the increasing dependence on imported energy. Net imports cover over $50 \%$ of gross available energy in the EU, with the energy dependence rate exceeding $50.0 \%$ [8].

Electricity consumption in the EU has been characterized by considerable changes. In the years 2005-2007, it increased rapidly, reaching its highest level of over 76,000 tonnes of oil equivalent (TOE) in 2007. This led to decisive action aimed at reducing this trend. In the following years, a decrease was observed, which may be connected with the consequences of the economic crisis in Europe. Slight increases in the successive years did not cause an increase in energy consumption over the 2007 level, whereas, at present (Table 1), a marked economic slowdown triggered by the negative effects of the Covid-19 pandemic has led to a decrease in energy consumption and a general reduction in negative anthropogenic impacts on the natural environment.

The data in Table 1 indicate that Poland is one of the EU's highest electricity consumers. At the same time, it predominantly relies on conventional energy sources (Figure 1). Solutions and regulations are being sought to minimize electricity consumption, regardless of the current condition of the economy. However, it is crucial to ensure the country's energy security [9].

EU policies set objectives that are important for global priorities for the protection and conservation of the natural environment. The effects of these policies can be identified, among others, in Poland, where dynamic changes in the diversification of energy generation are taking place, which is confirmed by the research. It should also be noted that the energy market in Poland is undergoing dynamic changes which greatly affect rural areas. At the same time, the level of regional development determines the development of the electricity market. 
Table 1. Electricity and heat generation in the EU countries (thousand tonnes of oil equivalent).

\begin{tabular}{|c|c|c|c|}
\hline Country/Period & 2017 & 2018 & 2019 \\
\hline EU-27 & $607,009.750$ & $594,147.245$ & $578,490.641$ \\
\hline Belgium & $18,552.910$ & $15,172.833$ & $19,293.727$ \\
\hline Bulgaria & $11,289.852$ & $11,207.263$ & $10,893.471$ \\
\hline Czechia & $21,816.784$ & $22,035.561$ & $22,233.952$ \\
\hline Denmark & 6704.290 & 6648.120 & 6148.094 \\
\hline Germany & $125,613.205$ & $121,608.696$ & $112,069.343$ \\
\hline Estonia & 3679.360 & 3558.216 & 2293.173 \\
\hline Ireland & 4801.722 & 4617.431 & 4472.922 \\
\hline Greece & $10,139.682$ & 9765.473 & $10,615.034$ \\
\hline Spain & $50,553.625$ & $48,240.888$ & $46,262.363$ \\
\hline Francje & $130,171.155$ & $132,728.853$ & $129,450.691$ \\
\hline Croatia & 1856.582 & 1930.725 & 1962.438 \\
\hline Italy & $55,904.390$ & $53,919.876$ & $53,787.109$ \\
\hline Cyprus & 1059.351 & 1074.845 & 1062.102 \\
\hline Latvia & 1588.248 & 1589.194 & 1531.975 \\
\hline Lithuania & 1762.408 & 1654.311 & 1604.404 \\
\hline Luxsemborg & 349.600 & 354.453 & 347.244 \\
\hline Hungary & 8528.965 & 8251.994 & 8393.807 \\
\hline Malta & 297.952 & 314.975 & 334.322 \\
\hline Holland & $21,907.670$ & $20,566.062$ & $21,192.037$ \\
\hline Austria & $10,549.253$ & 9975.852 & $10,341.393$ \\
\hline Poland & $41,250.397$ & $40,852.733$ & $38,536.183$ \\
\hline Portugal & 9798.661 & 9323.320 & 8047.017 \\
\hline Romonia & $13,005.711$ & $12,964.004$ & $12,106.492$ \\
\hline Slovenia & 3192.512 & 3095.545 & 3052.134 \\
\hline Slovakia & 6924.131 & 6451.268 & 6747.014 \\
\hline Finlandia & $15,192.384$ & $15,641.939$ & $15,260.934$ \\
\hline Switzerland & $30,518.950$ & $30,602.815$ & $30,766.528$ \\
\hline \multicolumn{4}{|c|}{ Descriptive statistic } \\
\hline minimum & 297.952 & 314.975 & 334.322 \\
\hline mean & $22,481.843$ & $22,005.454$ & $21,437.256$ \\
\hline median & $10,139.682$ & 9765.473 & $10,341.393$ \\
\hline variation efficiency $(\%)$ & 150.46 & 152.65 & 149.40 \\
\hline maximum & $130,171.155$ & $132,728.853$ & $129,450.691$ \\
\hline
\end{tabular}

Source of data: Eurostat.

This article aims to present:

- Changes in the electricity production market in Poland in the period from Poland's accession to the EU (considering its level and energy sources used);

- Electricity consumption in households in Poland in terms of time and region (depending on the location-rural vs. urban areas).

The research was conducted at the regional level (NUTS 2 until 2017). Secondary data from the Central Statistical Office (GUS) in the Local Data Bank were used, along with information from the European Commission and Eurostat websites.

The research problem is important from the point of view of sustainable development and environmental protection as well as the economic security of electricity consumers. This paper does not discuss all the aspects of energy economics; however, the analysis covered two key issues, i.e., the production and consumption of electricity.

\section{Background and Literature Review}

\subsection{EU Energy Policy}

Energy policy must be long-term and beneficial to all member states. Accordingly, the EU is implementing an energy policy covering the full range of sources, from fossil fuels to nuclear and renewable energy. The goal is to transform economies into lowenergy economies while ensuring greater security, competitiveness and sustainability of the energy used. 
It may be assumed that the EU project, consisting in the integration of economies after WWII and peaceful cooperation between countries, was based, among other things, on energy policy initially related to the coal market and, subsequently, also to nuclear energy. The foundations for this process were laid by the Treaty of Paris, establishing the European Coal and Steel Community (ECSC) signed in 1951, which entered into force on 23 July 1952. At that time, coal was the main energy source worldwide, and it accounted for approximately $70 \%$ of the total. The energy balance of the six member states showed considerable differences between individual countries, since in France it was approximately $60 \%$, whereas in Luxembourg it amounted to $95 \%$ [10]. In view of the current actions aiming at the establishment of a common energy market for the EU member states, cooperation within ECSC may be considered as the foundation for a common energy policy [11]. In turn, the Energy Card Treaty signed in 1991 by 46 countries is a document of significant importance, providing grounds for actions aimed at the improvement of energy efficiency and thus also the energy economy [11,12]. In their study, Grycan et al. indicated the following most important regulations in this respect [12]:

- The EU climate and energy package (September 2007), known for its 20-20-20 targets or the three " 20 targets" by 2020, assuming a reduction in greenhouse gas emissions by $20 \%$ in relation to the levels of 1990 , reduction in energy consumption by $20 \%$ compared to the EU forecasts for 2020, and an increase in renewable energy to $20 \%$ of the total EU energy consumption;

- The third energy package (September 2007), stipulating ownership unbundling, separating electricity and gas production from their transmission and a framework for enhanced mutual cooperation and aid in the case of threatened energy supplies;

- The climate and energy package (January 2008) comprising six proposals of legal acts concerning the promotion of renewable energy, vehicle $\mathrm{CO}_{2}$ emission standards, fuel specifications, joint efforts to reduce greenhouse gas emissions and development of carbon capture and storage as well as a review of the European system of emissions trading;

- The Commission Communication "Energy 2020" (November 2010), defining five current priorities for the energy sector, i.e., energy saving in the transport and construction sectors, establishment of an internal energy market along with the respective infrastructure, execution of the common European energy policy and European leadership in energy generation technologies and innovations as well as guaranteeing access to secure, reliable and competitively priced energy for Europeans;

- The third energy package (March 2011), comprising two market directives, two transmission regulations and a regulation establishing the Agency for the Cooperation of Energy Regulators;

- The Communication from the European Commission on the plan to ensure energy efficiency and a roadmap for moving to a competitive low carbon economy in 2050 (March 2011), presenting a proposal to the EU member states for a joint strategy to convert to low carbon energy economies;

- Directive 2012/27/EU of the European Parliament and Council on energy efficiency, (10.2012) amending Directives 2009/125/EC and 2010/30/EU and repealing Directives 2004/8/EC and 2006/32/EC.

It seems that a milestone in the EU energy policy was the adoption of a strategy establishing the energy union, which reflected the new concept of energy security for the EU countries [13]. Its aim was to establish the energy union, which would provide secure, sustainable, competitive and reasonably priced energy supplies to EU households and enterprises.

A natural continuation of actions related to the development of the energy union was provided by the "clean energy for all Europeans" package [14]. Its objectives included, first of all, energy efficiency and increased energy production from renewable sources, with the simultaneous assurance of cheap energy accessible to all consumers. Thanks to the implementation of measures leading to modernization of the EU economies (Figure 2), it is 
assumed that the intensity of $\mathrm{CO}_{2}$ emissions will be reduced by over $40 \%$, while renewable sources will account for approximately $50 \%$ all electricity $[15,16]$. A significant component in this reform package for the energy market is related to the need for a 10-year integrated national energy and climate plan for the years 2021-2030.

The EU energy policy in the 2030 perspective- - setting out national strategies-includes three primary goals [17]:

- Minimization of energy prices;

- Ensuring an appropriate level of energy security;

- Minimizing the consequences of energy technologies that are harmful to the environment.

Both for the Polish economy and the entire population, an important planning document is the Energy Policy of Poland by 2040 (PEP 2040) [18], which has been considerably modified by arrangements in the climate and energy policy adopted at the EU level. The essence of Poland' energy policy by the year 2040 is based on three pillars:

I. Just transformation;

II. A zero-emission power engineering system;

III. Good air quality.

The above-mentioned three pillars of the energy policy comprise eight specific goals, of which some directly concern the power sector, including green power engineering, which jointly constitute an energy supply chain, starting from the acquisition of raw materials and energy generation and supply, as well as energy use and sale, at the same time maintaining energy security for consumers.

\subsection{Economic Transformation for Sustainable Development}

The EU energy policy indicates the direction of activities oriented towards sustainable development, of which energy is an essential factor.

The concept of sustainable development [19-22] in the following decades was acknowledged and incorporated into various forms of socio-economic development.

The concept of sustainable development includes the following aspects: humans as subjects affecting the environment, our planet as an object of human activity and the mode of action, i.e., partnership, since only integrated measures will facilitate achieving the goal of the concept, i.e., sustainable prosperity [23]. Thus, sustainable development promotes environmental protection and, by preventing the over-exploitation of natural resources, it protects them for future generations.

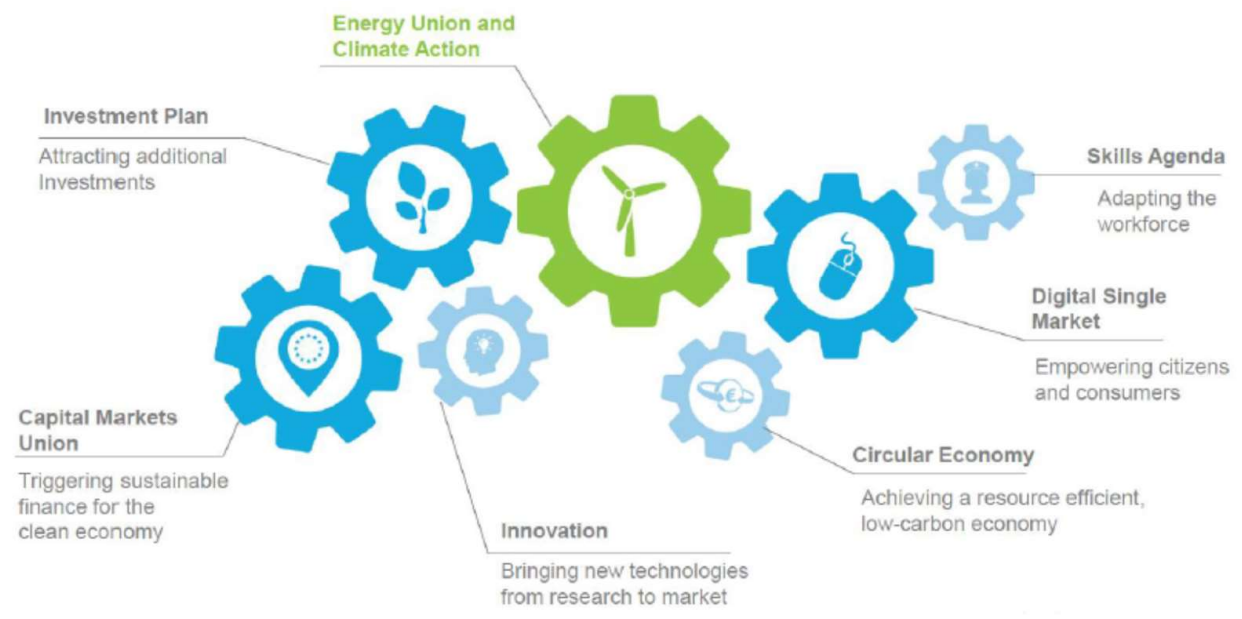

Figure 2. Role of the energy union and climate action. Source: [23].

In the EU countries, the concept of sustainable development has been an important part of economic development strategies for several decades. It is incorporated into the strategic socio-economic policies in all these countries, while being based on climate stability. When considering the implementation of sustainable development, we need 
to focus on the Europe 2020 strategy and the European Green Deal. One of the leading directions for the implementation of sustainable development within the Europe 2020 strategy has been connected with meeting the requirements of the climate and energy policy in the EU. In terms of the operations, it is intended to achieve goals such as a reduction in $\mathrm{CO}_{2}$ emissions and reduced consumption of fossil fuels, particularly coal, since this exhibits the greatest emission loads. Such goals are to promote a low-emission economy, protecting sustainable resources both for the present and future generations. Figure 3 presents the primary environmental goals of Agenda 2030 and the Europe 2020 strategy as an intermediate stage in the execution of the ultimate goals. The goals established provide direction to national changes in the energy policy in the EU countries.

There are paths ("trajectories") to the RES target, i.e., presentations of the rate of implementation of the contribution in the period 2021-2030. These are agreed on individually with each country; however, they are not arbitrary. The regulations indicate the minimum levels of RES share in specific years [24]:

- In 2022-at least $18 \%$ of the planned (for 2030) RES growth share in the period 2021-2030;

- In 2025, at least $43 \%$;

- In 2027 , at least $65 \%$.

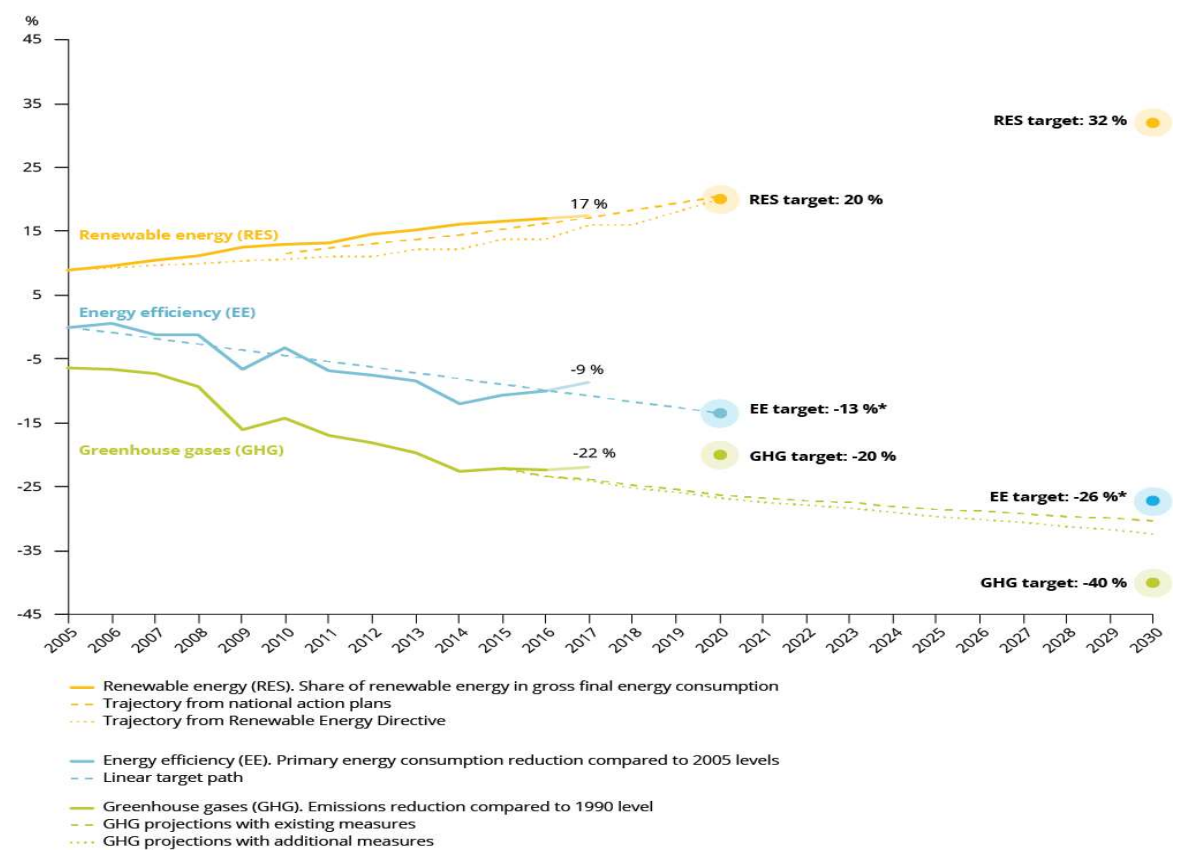

Figure 3. Selected Agenda 2030 goals. Source: [25].

Within the next three decades, more ambitious goals have been proposed for sustainable development in the EU countries by updating the list of climate and environmental problems which need to be solved, as specified in the European Green Deal strategy [26-29].

The European Green Deal (Figure 4) is a new strategy for growth, aimed at transforming the EU into a fair and prosperous society with a technologically advanced, resourceefficient and competitive economy, which will reach zero net greenhouse gas emissions by 2050 and within which economic growth will not be dependent on the consumption of natural resources [26]. 


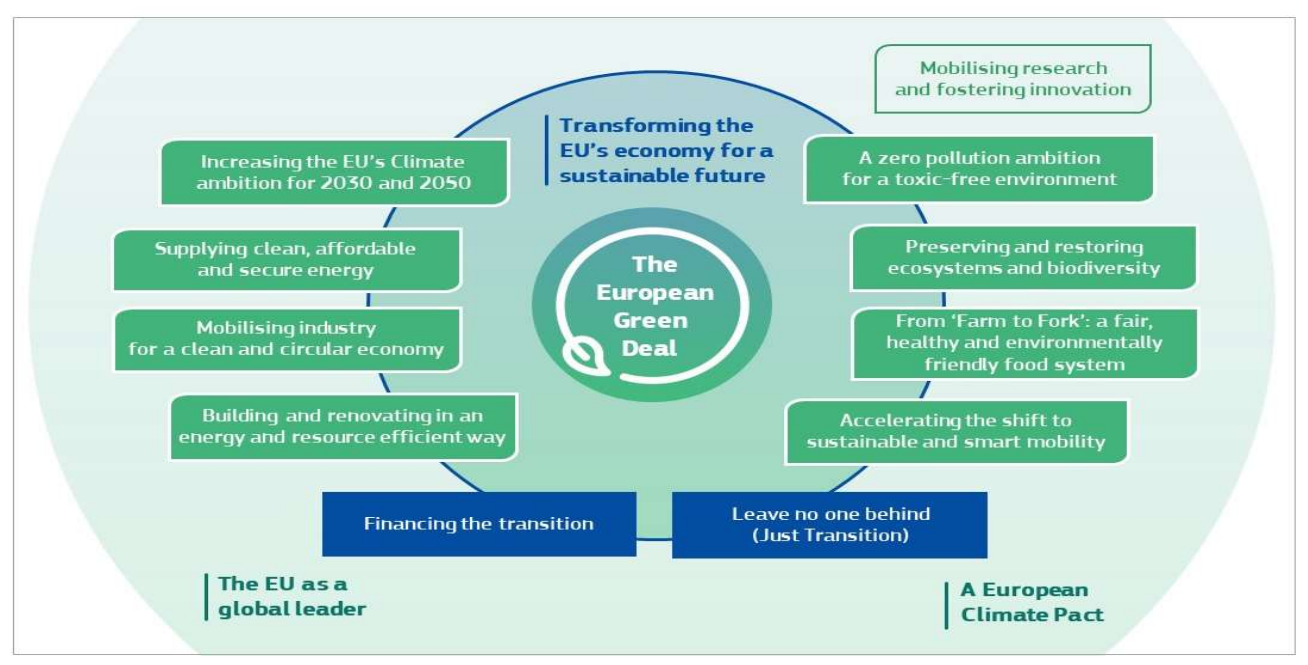

Figure 4. The European Green Deal. Source: [26].

Such a goal is a very ambitious developmental challenge both economically and socially. However, it is advisable to undertake such challenges considering potential benefits resulting from the reduction or possibly even halting of the progressive increase in global temperatures and environmental degradation, as well as the resulting climate change. The European Green Deal 2050 adopted by the EU is in line with the guidelines for the protection of climate and the natural environment within the UN 2030 sustainable development agenda, i.e., actions undertaken on the global scale in terms of environmental protection and responsible environmental management.

The essence of the EU economic transformation aimed at a sustainable future will be based on the joint funding of green investments and the simultaneous financial involvement of public and private stakeholders in the transition process. Moreover, it needs to be a just transformation, concentrating on the regions and sectors that will suffer most from its consequences due to their dependence on fossil fuels and high-emission processes. Within the cohesion policy, the Just Transformation Fund (JTF) is a new financial instrument covering the years 2021-2027, providing financial support to regions suffering serious socioeconomic problems resulting from the transformation aimed at climate neutrality [27-29]. The Fund resources will curb the negative social, economic and environmental impacts of the energy transformation. Most probably, the funds will provide support to beneficiaries from the Ślaskie, Dolnoślaskie and the Wielkopolskie provinces, while the government is also trying to make the support available also to the Lubelskie, Łódzkie and Małopolskie provinces. Nevertheless, the national budgets will continue to play a key role in the green transformation processes, among other things using green budgeting tools, facilitating the transition of public investment and consumption and tax systems to further environmental priorities and reduce further degradation of the natural environment.

Realization of the economic transformation towards a sustainable future for the EU countries will be based on the following strategic tasks:

- Adoption of more ambitious EU climate goals for 2030 and 2050:

- Provision of clean, reasonably priced and secure energy;

- Mobilization of the secondary sector to implement the circular economy model;

- Building and renovating in an energy and resource-efficient manner;

- Zero emissions for a non-toxic environment;

- Conservation and restoration of ecosystems and biodiversity;

- The From Farm to Fork Strategy - a fair, healthy and environmentally friendly food production system;

- Accelerating the shift to sustainable and smart mobility;

- Supporting research and fostering innovations. 
Gradual and successful implementation of the strategic tasks in the following years will result in positive changes, while, at the same time, the EU countries may become world leaders in preventing climate change and environmental degradation.

In view of these expected changes, the Executive Vice-President of the European Commission Frans Timmermans stated: "We must show solidarity with the most affected regions in Europe, such as coal mining regions and others, to make sure the Green Deal gets everyone's full support and has a chance to become a reality" [30].

As indicated by Jonker and Krukowska [31], the creation of "green economy" in all industrialized countries will establish a boundary between the two eras. A green economy is a circular economy. Its essence is manifested in the fact that changes progress from one phase to the next, followed by the return to the transitional phase, which reverses the previous linear economic system if changes follow the "make-take-dispose", stepby-step direction. The term green economy was first used by David Pearce [32], who observed that sustainable development is impossible in the current economy dependent on depleting resources such as oil and coal [33]. The green economy model involves low carbon dioxide emissions, efficient utilization of natural resources and the inclusion of all groups and individuals.

A green transformation both of the global and EU economies is becoming an increasingly accepted form of economic development. Such a socio-economic development is more and more universally accepted thanks to the potential positive effects of the green economy, with its environmentally friendly development pattern. Another crucial aspect is connected with the fact that the green transformation is to be a fair one, which means that inhabitants of the affected regions will not be disadvantaged and left alone but will be presented with a viable alternative. Such an approach seems to be highly beneficial for Poland, since our country may be the greatest beneficiary of this fund, with the allocated financial resources reaching two billion euro, i.e., approximately a quarter of the entire JTF. However, it needs to be remembered that the real absorption of funds is dependent on the acceptance of the Paris Agreement goals by the prospective beneficiary. For the time being, Poland is the only country which has refused to join in the climate neutrality goal, arguing that this stems from the specific character of its domestic energy sector, which needs much more time to adapt to changes, while automatic acceleration of energy transformation would involve huge social costs, greatly exceeding the amount allocated to Poland in the JTF. As a result, the real funds would be only $50 \%$ of those originally allocated.

The success of the green transformation in the EU countries, aimed at achieving climate neutrality by 2050 through the decarbonization of economies, will depend to a considerable extent on transformation programs such as the Regional Just Transformation Plans. In the opinion of officials from the Ministry of Development Funds and Regional Policy " ... the aim is to develop plans, which will ensure sustainable and just solutions for mining regions. The Regional Just Transformation Plans need to be compatible with the national energy and climate plans" [34].

\subsection{Challenges in the Strategic Goal: Provision of Clean, Reasonably Priced, and Secure Energy}

In view of prevention of further climate change and progressive degradation of the natural environment throughout the EU, the primary issue is to implement the strategic goal ensuring the "provision of clean, reasonably priced and secure energy." EU countries' previous experience indicates that over $75 \%$ of greenhouse gas emissions are generated by the production and use of energy [35]. Such a high share of greenhouse gas emissions from the energy sector results from the predominant use of carbon energy carriers. To date, less than $18 \%$ of gross final energy consumption in the EU countries in 2017 has come from renewable energy sources [36]. The forecast objective in this respect in 2020 was $20 \%$. In view of the current data in some EU countries, there is a risk of failing to reach the expected objective, with a serious risk of such failure indicated for such countries as Belgium, France and Poland, while a moderate risk is suggested for Luxembourg and the Netherlands. In turn, based on estimates for all the EU-28 countries, the probable share of renewable energy 
in 2020 was approximately 23\% (For the group of EU-27 countries (excluding Great Britain) this level will amount to approximately $24 \%$.); thus, it would be higher than expected [37]. This indicates the internal diversification between the EU-28 countries in terms of the development of renewable energy and achieving the adopted goals. The energy sector based on renewable energy needs to be further developed. To a considerable degree, this will facilitate the elimination of coal as the main source of energy, while at the same time reducing the emission levels in the economy.

The transition to clean energy is a long-term process, consisting of the transformation of the power engineering system; while ensuring the effectiveness of these changes, it will be necessary to involve all consumers and gain their acceptance thanks to the economic benefits offered and the awareness of the need for change. In the transition to clean energy, a key role will be played by renewable energy sources. The European Commission Communication [29] expressed an opinion that: "Increasing offshore wind production will be essential, building on regional cooperation between Member States. The smart integration of renewables, energy efficiency and other sustainable solutions across sectors will help to achieve decarbonisation at the lowest possible cost. The rapid decrease in the cost of renewables, combined with improved design of support policies, has already reduced the impact on households' energy bills of renewables deployment".

Nevertheless, some households still face the problem of energy poverty [38]. In view of the above, considering the poorest part of the population, special measures need to be introduced to protect financially stressed households when they cannot afford indispensable energy services to maintain a basic standard of living. The most important role is played by effective initiatives, e.g., those which may in the future reduce energy bills and which, through specific solutions, will have a positive and advantageous impact on the condition of the natural environment.

At present, individual countries are only starting the long process of transition to a lowemission power generation system and the low-emission economy. Profound changes related to energy transformation will require considerable public and political support. It is energy prices and the costs of energy transformation that should stimulate market transformation to achieve a climate-neutral economy within the next few decades. To ensure the success of the entire transition process, it is essential for energy consumers, both households and businesses, to have access to reasonably priced energy. In the last five years, an upward trend for wholesale electricity prices has been evident in the EU countries, followed by rising retail prices for end users. A culmination of the wholesale price increases was recorded in 2018, followed in 2019 by a reduction in prices mainly thanks to decreasing consumer demand as well as the rapid increase in the supply of renewable energy. In the EU countries, this phenomenon was far from universal; as a result, the diversification in price levels between the regional markets grew. In the first half of 2020 compared to the analogous period in 2019, prices dropped by $30 \%$ in some regional markets in southern Europe and up to $70 \%$ in certain northern regions [39]. This diversified reduction is explained by insufficient interconnection capacity, differences in the production of renewable energy on individual markets and the considerable growth of $\mathrm{CO}_{2}$ prices, which had a considerable impact particularly in the EU countries with greater shares of fossil fuel in their energy basket. Thus, it stresses the need for additional investment in grid flexibility, transboundary transmission capacity and renewable energy sources, particularly in EU countries that are falling behind in this respect, which should, in the future, result in greater price integration of electricity between the regional markets and benefits for consumers. Taking the existing needs into consideration, achieving climate neutrality requires an intelligent infrastructure. Strengthening transboundary and regional cooperation between countries will benefit from the transition to affordable clean energy. Thus, it will be necessary to review the frameworks regulating the energy infrastructure, including the TEN-E regulation 12, in order to ensure cohesion aimed at climate neutrality. These frameworks need to promote innovative technologies and infrastructure, such as intelligent grids, hydrogen networks or the capture, storage and disposal of carbon 
dioxide as well as energy storage, while facilitating sector integration. Nevertheless, the general public has to realize that certain existing facilities and infrastructure will have to be modernized to further serve their role and resist climate change.

Energy consumers may be concerned about price levels on the retail electricity markets since, in the last decade, these have kept rising. In the years 2010-2019, electricity prices for households were increasing at $2.3 \%$ annually, while the general prices of consumer goods increased by $1.4 \%$ [39]. Over the same period, an increase was also recorded for electricity prices for business consumers; however, in this case, the annual mean growth rate was $1.1 \%$. In turn, for energy consumers such as large industrial enterprises, energy prices decreased by 5\%, in the 2010-2019 period; thus, they were advantageous for this group of consumers. Energy prices for the end users are determined by a variety of factors. These obviously include wholesale prices, but also grid charges as well as taxes and other fees, such as the current subsidies for renewable energy or the costs of energy-supply commercialization. At present, it is taxes and charges that are the most important cause of differences in retail prices at the regional level.

Results of the latest analyses of energy prices in the EU have confirmed considerable differences in taxation of electricity consumption between individual EU countries and, as a consequence, the impact of this element on retail energy prices. In 2019, environmental taxes paid by households ranged from $1 \mathrm{EUR} / \mathrm{MWh}$ in Luxembourg to $118 \mathrm{EUR} / \mathrm{MWh}$ in Denmark, while VAT rates ranged from $5 \%$ in Malta to $27 \%$ in Hungary. Fees charged on renewable energy range from 3 EUR/MWh in Sweden to $67 \mathrm{EUR} / \mathrm{MWh}$ in Germany. Moreover, in most countries, taxes and fees, as well as grid charges (i.e., the two price elements defined based on regulatory measures), considerably exceed the element imposed on energy and determined by market mechanisms.

\section{Materials and Methods}

This study is based on data from the Local Data Bank of the Central Statistical Office (Statistics Poland), titled Electricity in households by consumer location [40]. Moreover, both national and international reports were used along with numerous studies concerning electricity production and consumption in general, particularly in rural areas. The problems investigated were analyzed in terms of development conditions resulting from the EU development strategy by 2050 referred to as the European Green Deal and the Energy Policy of Poland by 2040.

The primary aim of this study was to identify homogeneous groups of provinces (województwa) characterized by a comparable rate of change in electricity consumption considering changes observed in rural areas. Moreover, the level, directions and rate of changes in electricity generation and consumption were also investigated.

The subject of studies on the energy economy presented in this paper are related to energy production, taking into consideration energy carriers used in the generation processes and electricity consumption in households by consumer location. Thus, energy consumption was analyzed separately for rural areas compared to urban areas or the overall consumption on the national level.

In the case of electricity production, its generation was analyzed for two periods, 2004 and 2019. In this way, the direction of change, the dynamics and the mean annual rate of change in electricity production in Poland were compared for these two periods, considering the environmental impact of energy generation processes, and assuming that an advantageous situation would be manifested in a situation considered to be desirable, i.e., the share of energy generated using fossil fuels will decrease in successive years, being replaced by renewable energy. In the case of electricity consumption in households, the time frame for the analyses covered the years 2004-2019.

A separate analysis was conducted for energy consumption in households in rural areas and in urban areas, thus identifying existing trends in this respect. It specified which of the areas contributes to a greater environmental load in absolute terms, resulting from higher electricity consumption. The rate of change in electricity consumption was also 
determined on a regional scale divided into rural and urban areas, which made it possible to identify which of the areas contributed to a greater environmental load related to growing electricity consumption in the period investigated. With the implementation of development assumptions stipulated by the EGD 2050 and a reduction in the negative anthropogenic impact on the environment, particularly by supplying clean and environmentally safe energy, it is crucial to have knowledge on the effect of these phenomena both in rural and urban areas. Insight into this problem will facilitate appropriate and adequate preventive or countermeasures addressing the needs identified. The degree of similarity was determined for the distribution of electricity consumption in the spatial unit system in rural and urban areas, applying Florence's coefficient $\left[\mathrm{L}_{1}\right]$ as presented by [41]:

$$
L_{1}=\frac{1}{200} \sum_{i=1}^{n}\left|u_{i r}-u_{i s}\right|
$$

where $u_{i r}=\frac{y_{i r}}{\sum_{j=1}^{n} y_{j r}} \cdot 100 \%$ and $u_{i s}=\frac{y_{i s}}{\sum_{j=1}^{n} y_{j s}} \cdot 100 \%$ are percentages of the $Y_{r}$ and $Y_{s}$ features, respectively, and $n$ denotes the number of objects $(i=1,2, \cdots, n)$.

The total coefficient of localization $L_{1}$ assumes values in the range of $\langle 0,1\rangle$, with the closer its value is to one, the greater the degree of discrepancy for the characteristic, while the closer the value is to zero, the greater the similarity.

Moreover, the degree of concentration of absolute electricity consumption in the system of spatial units in rural and urban areas made it possible to identify the degree of discrepancy in electricity consumption by provinces, while Florence's coefficient $\left[\mathrm{K}_{1}\right]$ was applied as proposed by [41]:

$$
K_{1}=\frac{1}{200} \sum_{i=1}^{n}\left|u_{i}-\frac{100}{n}\right|
$$

where $u_{i}=\frac{y_{i}}{\sum_{j=1}^{y} y_{j}} \cdot 100 \%$ is the percentage of the examined feature $\mathrm{Y}$, and $n$ denotes the number of objects $(i=1,2, \cdots, n)$.

Values of the coefficient are found within the range of $\langle 0,1\rangle$, with the coefficient value of 0 indicating a uniform distribution, i.e., lack of concentration, while the value of 1 denotes complete non-uniformity, i.e., complete concentration of the trait analyzed.

Analysis of the rate of changes made it possible to identify the existing trends in energy consumption in urban and rural areas. This was calculated on the basis of values throughout the entire period analyzed, which covered the years 2004-2019, applying the formula [41]:

$$
r g=\frac{-3 m+\sqrt{9 m^{2}+24 m(\mathrm{n}-1)\left(\frac{1}{y_{1}} \sum_{t=1}^{n} y_{t}-n\right)}}{2 m(n-1)}
$$

where: $y_{t}$ denoted the observation of the feature $\mathrm{Y}$ in the period $t, m=n(n+1)$ and $n$ is the number of periods $(i=1,2, \cdots, n)$.

Moreover, using the rate of change, the provinces were divided into homogeneous classes in terms of the scale of changes observed. This made it possible to distinguish regions of greater area, in relation to which similar instruments may be applied in the future to boost environmentally friendly actions. The classification of provinces from the high to the low rate of change was based, e.g., on an analysis of differences in the values of the rate of change. After the ordering of provinces according to the non-growing values of the rate of changes, differences were calculated between its values for neighbouring provinces, i.e., for the first and second, the second and the third, etc. Analyzing successive differences starting from the first (the difference between the second and the first province), a markedly higher value of this difference from the others will make it possible to distinguish classes of province with the highest rate of change, while the successive differences make it possible to identify the successive class. 


\section{Results}

\subsection{Electricity Production in Poland}

Analysis of the national energy system in 2004 and 2019 indicates advantageous changes in Polish electric power engineering in view of the goals of the energy policy by 2040. Between 2004 and 2019, a simultaneous increase was recorded in installed capacity and electricity production. The growth dynamics of installed power in that period amounted to almost $35 \%$, while electricity production increased by $3.5 \%$; thus, it was ten times lower. In 2004, total installed power was almost $35 \mathrm{GW}$, while it grew in the successive years to reach almost $47 \mathrm{GW}$ in 2019. Both in 2004 and 2019, the energy system was based primarily on carbon-based sources, with their share of the installed power types in power plants amounting to almost $60 \%$ and $50 \%$ for coal and $25 \%$ and $18 \%$ for lignite. Thus, in the next fifteen years, the share of carbon-based sources decreased by a total of approximately 17 p.p., including almost 10 p.p. for coal and by approximately 7 p.p. for lignite. In the analogous period, a gradual increase was observed in installed power based on gas-fired power plants, from less than $770 \mathrm{MW}$ to almost $2800 \mathrm{MW}$, while their share in the structure amounted to $2.2 \%$ and $6 \%$, respectively, i.e., it continued to be rather marginal despite the increase.

The analysis of data also showed that, in the following years, Poland realized that the process of gradual elimination of lignite as an energy source and a decreasing role of lignite-fired power plants in the national energy production system is indicated by the negative growth rate of installed power, the mean annual value of which was $-0.33 \%$ in the years 2004-2019.

In view of the challenges resulting from the implementation of the Polish energy policy by 2040 in the successive decades, in line with the guidelines in the EGD 2050, particularly provision of clean and secure energy, in the last fifteen years advantageous changes were introduced in the national electric power engineering system in Poland. First, in the successive years since Poland's accession to the EU, interest in renewable energy has been increasing.

According Arıoglu et al. [42], renewable energy is becoming the fastest growing energy source in the world. Gielen et al. [43] also note that renewable energy can meet two-thirds of the total global energy demand and, to a large extent, contribute to the reduction in greenhouse gas emissions responsible for climate change.

While, in 2004, wind power plants and renewable energy systems did not exist in Poland on a broader scale, by 2019 they had become a relatively important source of power in the national energy system. In 2019, wind power plants and other renewable energy sources accounted for almost $7500 \mathrm{MW}$, and their share in the total structure was $16 \%$, i.e., slightly less than the share of lignite-fired power plants $(17.9 \%)$, at the same time being over two-and-a-half times greater than gas-fired power plants (6\%) (Table 2). Simultaneously, in 2019, the production of what is defined as clean and secure energy in the regulations adopted within the EGD 2050 amounted to more than 14,000 GWh in Poland, at $9 \%$ of energy generation. This share exceeded that of energy from gas-fired power plants by 1.5 p.p. and was as much as six times greater than energy from hydro power (1.5\%). The conclusions provided by the observations of changes to hydro power in Poland between 2004 and 2019 are disturbing. This results from the drop in the energy generated from more than $3500 \mathrm{GWh}$ in 2004 to less than $2500 \mathrm{GWh}$ in 2019. The negative direction of change confirms the negative mean annual rate of change, which amounted to almost $(-2.4 \%)$ and, at the same time, was the highest of all other energy sources. This is a greater reduction than in the case of coal-fired power plants (mean annual decrease of less than minus $0.6 \%$ ) and lignite-fired power plants (mean annual decrease of approximately minus $1.5 \%)$. In view of the energy generation conditions in Poland, the most pressing need to reduce the energy sources in the national energy production system concerns coal- and lignite-fired power plants. Experience from the last fifteen years shows that this process is taking place in Poland; however, at a very slow rate. In view of the implementation of the objectives of the national energy plan PEP2040 and EGD 2050 in the coming years by 
providing consumers with clean and secure energy, further development of wind power and the use of other renewable energy sources needs to be promoted, together with the further development of gas-fired power plants, since this type of energy has a much less negative environmental impact. Experience in this respect obtained in the last fifteen years indicates that, in Poland, the use of gas in energy generation was developing dynamically, as indicated by the dynamics of change, amounting to almost $320 \%$, as well as the high mean annual rate of change, which was positive and amounted to approximately $8 \%$ for this type of installation.

Table 2. The National Electric Power System in Poland in 2004 and 2019.

\begin{tabular}{|c|c|c|c|c|c|c|c|c|c|c|c|c|}
\hline \multirow{3}{*}{ Specification } & \multicolumn{2}{|c|}{$\begin{array}{l}\text { Installed } \\
\text { Power }\end{array}$} & \multicolumn{2}{|c|}{ Production } & \multirow[t]{2}{*}{$\begin{array}{c}\text { Installed } \\
\text { Power }\end{array}$} & & \multicolumn{2}{|c|}{ Production } & \multicolumn{2}{|c|}{$\begin{array}{c}\text { Dynamics of Change } \\
2019[2014=100]\end{array}$} & \multicolumn{2}{|c|}{$\begin{array}{c}\text { Average Annual Rate } \\
\text { of Change [\%] }\end{array}$} \\
\hline & \multicolumn{4}{|c|}{2004} & & \multicolumn{3}{|c|}{2019} & & & & \\
\hline & MW & $\%$ & GWh & $\%$ & MW & $\%$ & GWh & $\%$ & $\begin{array}{l}\text { Installed } \\
\text { Power }\end{array}$ & Production & $\begin{array}{l}\text { Installed } \\
\text { Power }\end{array}$ & Production \\
\hline Professional power plants & 32,162 & 92.6 & 144,821 & 94.4 & 36,675 & 78.4 & 134,245 & 84.6 & 114 & 92.7 & 0.88 & -0.5 \\
\hline Professional hydropower plants & 2168 & 6.7 & 3525 & 2.4 & 2346 & 6.4 & 2454 & 1.8 & 108.2 & 69.6 & 0.53 & -2.38 \\
\hline Commercial thermal power plants: & 29,994 & 93.3 & 141,296 & 97.6 & 34,329 & 93.6 & 131,791 & 98.2 & 114.7 & 93.3 & 0.92 & -0.46 \\
\hline - hard coal & 20,411 & 68.1 & 85,370 & 60.4 & 23,159 & 67.5 & 78,190 & 59.3 & 113.8 & 91.6 & 0.87 & -0.58 \\
\hline - lignite & 8856 & 29.5 & 52,136 & 36.9 & 8382 & 24.4 & 41,502 & 31.5 & 95.2 & 79.6 & -0.33 & -1.51 \\
\hline - gas & 727 & 2.4 & 3791 & 2.7 & 2788 & 8.1 & 12,099 & 9.2 & 362.5 & 319.2 & 8.97 & 8.04 \\
\hline Wind farms and other renewable energy & - & - & - & - & 7490 & 16.0 & 14,344 & 9.0 & - & - & - & - \\
\hline Industrial power plants & 2553 & 7.4 & 8541 & 5.6 & 2634 & 5.6 & 10,178 & 6.4 & 103.2 & 119.2 & 0.21 & 1.18 \\
\hline Total & 34,715 & 100 & 153,362 & 100 & 46,799 & 100 & 158,767 & 100 & 134.8 & 103.5 & 2.01 & 0.23 \\
\hline
\end{tabular}

\subsection{Electricity Consumption in Poland Rural vs. Urban Areas}

Since Poland became an EU member, the entire country, including rural areas, has received new development opportunities. Accession to the EU and the related development policies, particularly the cohesion policy and the CAP, as well as the trade and industrial policies, provided a new economic and social quality. An important impulse for development has related to the targeted support from the EU funds addressing rural development in Poland. For example, allocation and utilization of the EU CAP funds are typically almost twice as high in Poland as the EU mean (the Polish agri-food sector and rural areas after ten-year EU membership - a review of major changes in 2014). Thus, the transfer of funds, also including public funds, has contributed to a boost in economic activity, which has been manifested in increased electricity consumption. Economic activity in rural areas measured by the number of economic entities in the REGON registry has improved considerably, as indicated by the almost 25\% increase in 2018 compared to 2010 (at that time there were 1.2 million out of the total 4.4 million entities), whereas, in towns and cities in the same period, the increase was as little as $8 \%$ [46].

Electricity consumption in Polish households in the last fifteen years has grown continuously. In 2004, it was 22.8 TWh, while, in 2019, it was 30.6 TWh, i.e., the absolute increase amounted to 7.8 TWh, or approximately a third in absolute terms (Figure 5). A particularly marked increase was recorded for energy consumption in rural areas, in 2004 consumers in those areas used 6.3 TWh electric energy, while in 2019 it was 12.7 TWh, an increase of $6.4 \mathrm{TWh}$. Rural areas were thus responsible for an over $80 \%$ increase in electricity consumption in Poland. This phenomenon was becoming even more pronounced in the successive years, since, while the share of rural areas in electricity consumption in Poland in 2004 was below 28\%, in 2019 it reached over 41\%. Rural areas in Poland are thus characterized by growing needs in terms of electricity supply. This is confirmed by the dynamics of changes in electricity consumption. While, in the extreme years, this amounted to slightly over $34 \%$, in urban areas it was less than $10 \%$, then in the same period in rural areas it was ten times higher, amounting to almost $100 \%$, which shows a doubling of electricity consumption (Table 3). In the regional system, the dynamics of change in electricity consumption varied between individual provinces (Table 3). First of all, it may be observed that, in contrast to rural areas, electricity consumption in urban areas is generally characterized by minor changes. In provinces such as Pomorskie, Łódzkie and Warmińsko-mazurskie, a highly stable level of energy consumption was recorded, 
while the dynamics of change in 2019 compared to 2004 did not exceed $2.5 \%$. Rural areas exhibited a much greater dynamic of electricity consumption in the years 2004-2019. In certain provinces, energy consumption increased several-fold. In the Podlaskie province, electricity consumption increased five-fold, while in the Łódzkie and Lubelskie provinces a minimum three-fold increase was recorded.

Table 3. Dynamics of change in electricity consumption in Poland (GWh).

\begin{tabular}{|c|c|c|c|c|c|c|c|c|c|}
\hline \multirow{2}{*}{$\begin{array}{c}\text { Consumption } \\
\text { Region }\end{array}$} & \multirow{2}{*}{$\begin{array}{l}\text { Total } \\
2004\end{array}$} & \multicolumn{3}{|c|}{ Urban Areas } & \multicolumn{2}{|c|}{ Rural Areas } & \multicolumn{3}{|c|}{$\begin{array}{c}\text { Dynamics of Change } 2019 \\
{[2004=100]}\end{array}$} \\
\hline & & 2019 & 2004 & 2019 & 2004 & 2019 & Total & $\begin{array}{l}\text { Rural } \\
\text { Areas }\end{array}$ & $\begin{array}{l}\text { Urban } \\
\text { Areas }\end{array}$ \\
\hline Poland & $22,804.4$ & $30,613.2$ & 6344.1 & $12,677.1$ & $16,460.3$ & $17,936.0$ & 134.2 & 199.8 & 109.0 \\
\hline Dolnośląskie & 1633.0 & 2373.4 & 403.2 & 839.7 & 1229.8 & 1533.7 & 145.3 & 208.2 & 124.7 \\
\hline Kujawsko-Pomorskie & 1151.6 & 1551.9 & 377.8 & 697.4 & 773.7 & 854.5 & 134.8 & 184.6 & 110.4 \\
\hline Lubelskie & 886.4 & 1448.9 & 266.1 & 803.9 & 620.3 & 644.9 & 163.5 & 302.1 & 104.0 \\
\hline Lubuskie & 599.3 & 794.7 & 170.3 & 296.0 & 429.0 & 498.7 & 132.6 & 173.8 & 116.3 \\
\hline Łódzkie & 1468.9 & 2041.5 & 276.2 & 830.5 & 1192.7 & 1211.0 & 139.0 & 300.7 & 101.5 \\
\hline Małopolskie & 2398.7 & 2858.0 & 1006.0 & 1393.9 & 1392.6 & 1464.2 & 119.2 & 138.6 & 105.1 \\
\hline Mazowieckie & 3508.4 & 5046.4 & 639.4 & 1820.2 & 2869.0 & 3226.2 & 143.8 & 284.7 & 112.5 \\
\hline Opolskie & 674.8 & 823.6 & 282.4 & 421.9 & 392.4 & 401.7 & 122.1 & 149.4 & 102.4 \\
\hline Podkarpackie & 786.9 & 1262.6 & 324.9 & 728.8 & 462.0 & 533.8 & 160.4 & 224.3 & 115.5 \\
\hline Podlaskie & 503.4 & 937.7 & 94.0 & 476.4 & 409.4 & 461.3 & 186.3 & 507.0 & 112.7 \\
\hline Pomorskie & 1517.8 & 1826.6 & 395.2 & 701.5 & 1122.6 & 1125.1 & 120.3 & 177.5 & 100.2 \\
\hline Śląskie & 3322.6 & 3688.1 & 698.7 & 954.9 & 2623.9 & 2733.2 & 111.0 & 136.7 & 104.2 \\
\hline Świętokrzyskie & 491.6 & 794.2 & 172.2 & 427.5 & 319.4 & 366.7 & 161.6 & 248.3 & 114.8 \\
\hline Warmińsko-Mazurskie & 788.0 & 1029.5 & 258.5 & 488.5 & 529.5 & 541.0 & 130.7 & 189.0 & 102.2 \\
\hline Wielkopolskie & 2061.0 & 2880.0 & 745.7 & 1394.3 & 1315.3 & 1485.6 & 139.7 & 187.0 & 113.0 \\
\hline Zachodniopomorskie & 1012.1 & 1256.0 & 233.5 & 401.7 & 778.6 & 854.3 & 124.1 & 172.0 & 109.7 \\
\hline \multicolumn{10}{|c|}{ Descriptive statistics } \\
\hline minimum & 491.6 & 794.2 & 94.0 & 296.0 & 319.4 & 366.7 & 111.0 & 136.7 & 100.2 \\
\hline mean & 1425.3 & 1913.3 & 396.5 & 792.3 & 1028.8 & 1121.0 & & & \\
\hline median & 1081.9 & 1500.4 & 303.7 & 715.2 & 776.2 & 854.4 & 136.9 & 188.0 & 110.1 \\
\hline Coefficient of variation (\%) & 67.0 & 62.8 & 62.9 & 53.5 & 74.2 & 74.3 & & & \\
\hline maximum & 3508.4 & 5046.4 & 1006.0 & 1820.2 & 2869.0 & 3226.2 & 186.3 & 507.0 & 124.7 \\
\hline
\end{tabular}

Source: [44]. https://bdl.stat.gov.pl/BDL/dane/podgrup/temat/11/57/1880, accessed on 12 September 2021.

Mean annual rate of change in electricity consumption in households (Table 3) in rural areas of Poland on average was almost nine times greater than in urban areas, $6.51 \%$ compared to $0.74 \%$. The greatest growth rate for electricity consumption in rural areas was found in the Podlaskie and Lubelskie provinces, at almost $20 \%$ and $12.5 \%$, respectively (Table 4).

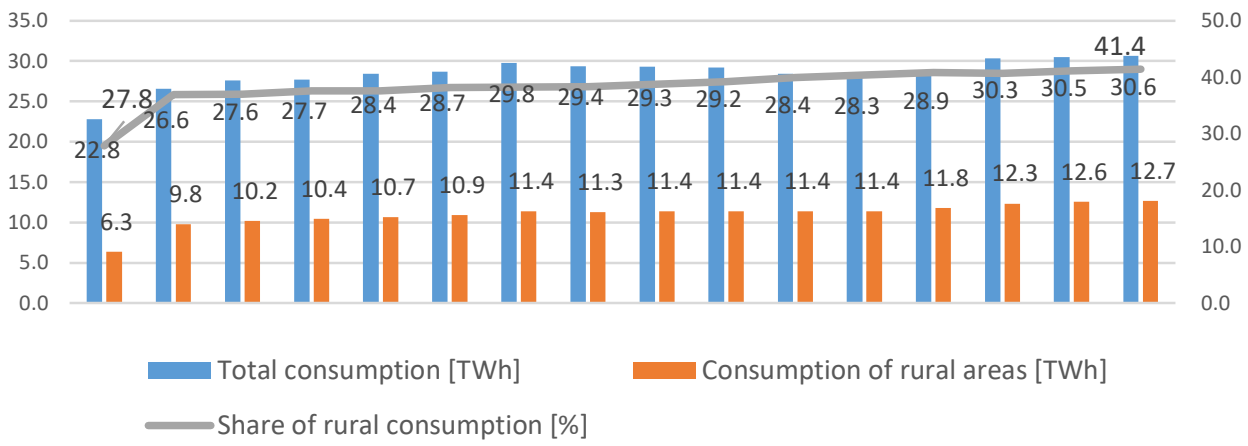

Figure 5. Electricity consumption in households in Poland in the years 2004-2019 (TWh). Source: [44]. 
Table 4. The rate of change in electricity consumption in households in Poland in the years 2004-2019 (\%).

\begin{tabular}{lccc}
\hline \multicolumn{1}{c}{ Region } & Total & Urban Areas & Rural Areas \\
\hline Poland & 2.61 & 0.74 & 6.51 \\
Dolnośląskie & 3.04 & 2.06 & 5.66 \\
Kujawsko-Pomorskie & 2.91 & 0.95 & 6.19 \\
Lubelskie & 5.26 & 0.70 & 12.57 \\
Lubuskie & 2.14 & 0.75 & 5.09 \\
Łódzkie & 3.20 & 0.38 & 11.48 \\
Małopolskie & 1.20 & 0.27 & 2.38 \\
Mazowieckie & 3.04 & 0.65 & 10.58 \\
Opolskie & 2.25 & 0.53 & 4.30 \\
Podkarpackie & 4.67 & 1.31 & 8.42 \\
Podlaskie & 6.34 & 1.22 & 19.68 \\
Pomorskie & 1.77 & 0.51 & 4.78 \\
Śląskie & 0.87 & 0.47 & 2.25 \\
Swiętokrzyskie & 4.81 & 1.04 & 10.01 \\
Warmińsko-Mazurskie & 2.57 & 0.44 & 6.07 \\
Wielkopolskie & 2.67 & 0.84 & 5.38 \\
Zachodniopomorskie & 1.69 & 0.62 & 4.72 \\
\hline
\end{tabular}

Source: authors' calculations based on Local Data Bank [44], https://bdl.stat.gov.pl/BDL/dane/podgrup/temat/ $11 / 57 / 1880$, accessed on 12 September 2021

Analyzing unit electricity consumption in Poland in the years 2004-2019 (Figure 6), i.e., per capita, with the division into rural and urban areas, it may be indicated that a characteristic event took place in 2014. For the first time in Poland, unit electricity consumption was higher in rural areas than in urban areas-by $1.4 \%$. In the following years, this phenomenon grew. As a result, in 2019, unit electricity consumption in rural areas was already $6.3 \%$ higher and amounted to $827 \mathrm{kWh}$ compared to $778 \mathrm{kWh}$.

A comparison of the degree of concentration of electricity consumption by provinces between rural and urban areas suggests a low degree of concentration for electricity consumption by province both in rural and urban areas (Table 5). Analogously, a close similarity is also observed in electricity consumption between rural and urban areas, as evidenced by similar values of the coefficient of similarity according to Florence (Table 5). In Poland, only in the Podlaskie province in the years 2004-2019, was a high growth rate for electricity consumption observed (Figure 7). In the next five provinces, i.e., Mazowieckie, Lubelskie. Podkarpackie, Świętokrzyskie and Łódzkie, electricity consumption increased at a medium rate. In the other provinces, it exhibited a low growth rate.

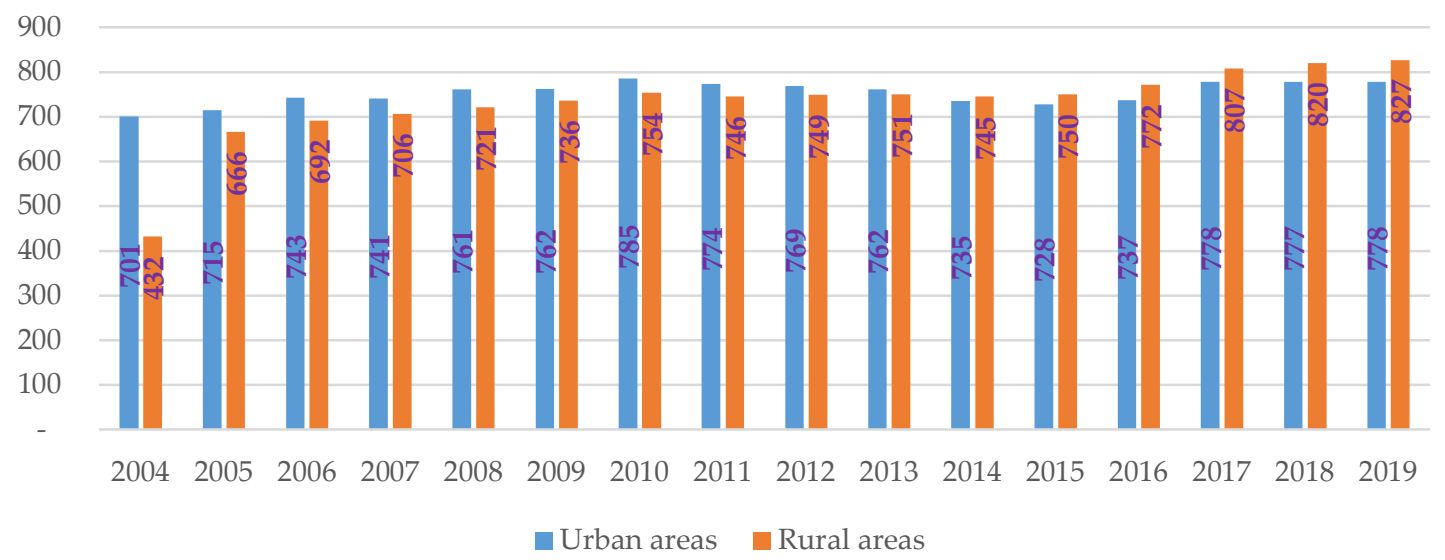

Figure 6. Unit electricity consumption in Poland (kWh/per capita). Source: authors' calculations based on Local Data Bank [44]. 

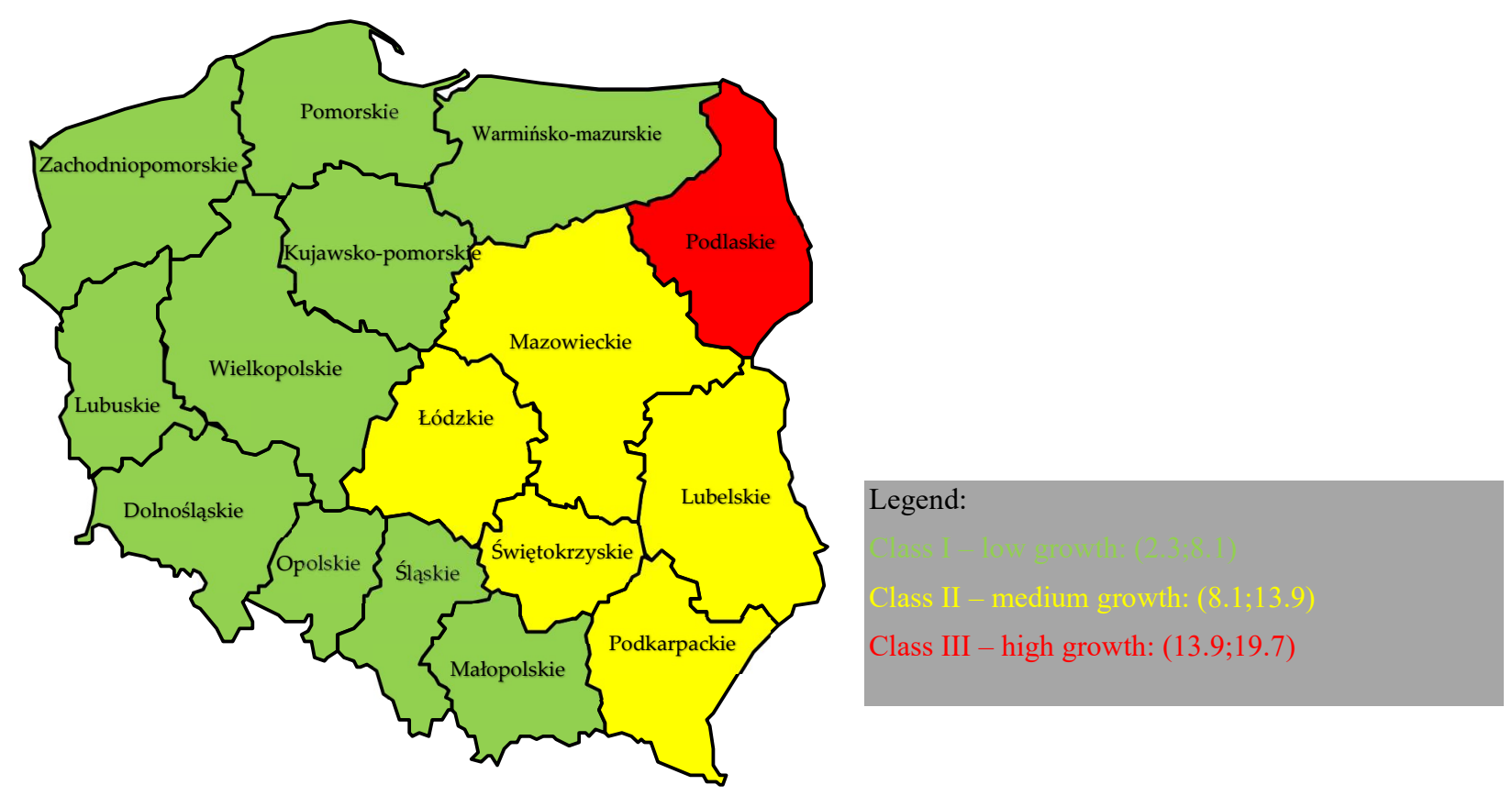

Figure 7. Regional variation in electricity consumption in rural areas of Poland in the years 2004-2019 according to mean annual rate of changes. Source: authors' study based on Table 3.

Table 5. The degree of similarity and concentration of electricity consumption.

\begin{tabular}{ccccc}
\hline \multirow{2}{*}{ Year } & \multicolumn{2}{c}{ Concentration } & \multicolumn{2}{c}{ Similarity } \\
\cline { 2 - 5 } & Rural Areas & Urban Areas & Rural Areas & Urban Areas \\
\hline 2004 & 0.24 & 0.28 & 0.04 & 0.04 \\
2005 & 0.19 & 0.28 & 0.05 & 0.03 \\
2006 & 0.18 & 0.27 & 0.06 & 0.03 \\
2007 & 0.19 & 0.27 & 0.05 & 0.03 \\
2008 & 0.19 & 0.27 & 0.05 & 0.03 \\
2009 & 0.19 & 0.27 & 0.05 & 0.03 \\
2010 & 0.19 & 0.27 & 0.06 & 0.03 \\
2011 & 0.19 & 0.27 & 0.05 & 0.03 \\
2012 & 0.19 & 0.28 & 0.05 & 0.03 \\
2013 & 0.19 & 0.28 & 0.05 & 0.03 \\
2014 & 0.19 & 0.27 & 0.05 & 0.03 \\
2015 & 0.19 & 0.27 & 0.04 & 0.03 \\
2016 & 0.19 & 0.27 & 0.04 & 0.03 \\
2017 & 0.19 & 0.27 & 0.04 & 0.03 \\
2018 & 0.19 & 0.27 & 0.04 & 0.03 \\
2019 & 0.20 & 0.27 & 0.04 & \\
\hline
\end{tabular}

Source: authors' calculations based on Local Data Bank [44].

\section{Discussion}

The energy market in Poland is undergoing dynamic changes that affect rural areas. Since 2014, unit electricity consumption per capita in rural areas exceeded the level of consumption in urban areas. This relationship is permanent, since it has been evident in the following years, while, additionally, differences in the level of consumption also grew in subsequent years.

Rural areas in Poland are characterized by a growing need for electricity. The scope of the research made it possible to track the existing trends in electricity consumption. Moreover, the provinces of Poland were grouped based on the growth rate of their electricity consumption. Classes characterized by low, medium and high growth rates were distinguished. The analysis was carried out for rural areas in Poland, which show great 
territorial differences in the level of socioeconomic development. This is understood as changes taking place in a direction that meets the collective and individual needs and individual aspirations of residents and local communities to an ever-greater extent [47]. At the same time, the level of regional development determines the development of the electricity market. The voivodships with a high and medium growth rate of electricity consumption include rural areas, which are characterized by a very low and low socioeconomic development.

The results indicate that, currently, rural areas contribute to the high adverse impact on the natural environment in Poland, which is the result of differences in specific energy consumption. In terms of the spatial arrangement, Podlaskie Voivodeship has a unique situation. This voivodeship had the highest increase in electricity consumption per capita in 2004-2019 (on average it was almost 20\%).

The changes observed are related to the increase in economic activity in rural areas, the intensification of agriculture and the increase in the scale of livestock production on farms. According to Wójcicki [48], animal breeding is more energy-consuming than arable farming.

In Poland, Podlaskie Voivodeship has the highest cattle population per 100 ha of UAA. This creates excellent opportunities for biogas production due to the increased availability of the substrate. There are therefore possibilities to limit the negative impact of Podlaskie Voivodeship on the environment in the future. This reduces $\mathrm{CO}_{2}$ emissions, particularly those from rural areas, and reduces the electricity consumption generated from fossil fuels. In the conditions of the energy transformation consisting of abandoning coal, a good state energy policy is needed [49]. Also, activities at the regional level support the existing solutions at the national level, for example, support from EU funds for investments in agricultural biogas plants.

Experience from the global energy market shows that it is possible to shift from fossil fuels to clean energy as the world moves towards decarbonizing economies and reducing greenhouse gas emissions worldwide [50]. As a result, environmental targets are no longer seen as an obstacle to economic development but as a solution to economic and social development.

According to Kaygusuz [51], renewable energy sources are a desirable form of practical solutions in the energy sector to develop clean and sustainable energy to reduce environmental pollution.

Over ten years ago, Marecki [52] and Jaczewski [53] indicated that, around 2020, the following may be expected:

- A moderate increase in the consumption of solid fuels, i.e., coal and lignite, in energy generation;

- A relatively low growth in oil consumption;

- A simultaneous high growth in natural-gas consumption;

- A very high increase in the production of renewable energy, whose share in the global energy consumption may increase to over 12 percent by 2020 .

The results of the study confirm the accuracy of these forecasts; particularly in the Polish energy economy in the last fifteen years, a considerable increase has been recorded in natural gas consumption for electricity generation along with a dynamic development of renewable energy [54]. A gradual reduction in the use of coal for electricity production has also been observed, although the rate of changes in this respect is not adequate to meet the existing challenges. These gradual changes in the consumption of energy carriers are consistent with the strategic EU goals. Thanks to further actions resulting from the Polish national energy plan PEP 2040, in the coming years, the energy economy in Poland will be increasingly compatible with that of the EU.

Within approximately the last two decades, Poland has made progress in reducing the negative environmental impact of electricity production, and the reduction in coal and lignite consumption on average by $0.6 \%$ and $1.5 \%$ confirms this. 
In the following years, the development of renewable energy generation may also be observed. In 2019, the share of electric energy produced by wind power as well as other renewable energy sources was $9 \%$, while, together with hydro power plants, it amounted to more than $10 \%$. Poland has reserves in the potential for clean energy generation, as indicated by the available production capacity which, for the two types together, amounts to $21 \%$ of total installed power in Poland.

Moreover, the realization of renewable energy investments with the support of EU funds in many local government units [54], also in rural communes, will, in the immediate future, bring an increase in the share of renewable energy.

Investments in renewable energy sources are desirable in rural areas. Sutherland et al. [55] highlight the countryside and the potential of agriculture to generate renewable energy. They indicate that, due to its historic commitment to managing essential resources, especially land and biomass, the agricultural sector plays, or at least can play, an important role in the transformation of renewable energy.

However, special care should be taken to ensure that the production of renewable energy in rural areas does not result in competition for food and energy resources, which could result in a deterioration of food security [56].

There are possible solutions that minimize the occurrence of such a phenomenon. According to Jasiulewicz [57], for example, to produce biomass, we should use lower quality soils that have been set aside, degraded or are at least not suitable for food production. The production of renewable energy in rural areas can also be based to a greater extent than before on biogas and the use of agriculture waste, which may be slurry or manure from the breeding of cattle, pigs or poultry [58-60].

\section{Conclusions}

Forecasted changes and the transformation of energy systems both in Europe and worldwide are taking place under the influence of the so-called development megatrends [61]. The most important of these in the European power engineering include decreasing costs of renewable, limitation of the environmental impact of the energy sector, the decreasing role of coal as an energy source and new business models in power engineering. On the international and EU scales, in the last five years, we have witnessed many crucial events and agreements, which, during the coming decades, will influence changes in the energy sector. These include the Paris Agreement on the global reduction of climate change, the adoption of the European Green Deal 2050, aimed at a zero-emission economy, and actions to introduce the Energy Union. National energy policy needs to adapt to such conditions on the macro scale, as new challenges have also appeared. The most important of these include the following issues: how to ensure energy security in a changing energy market? What might the future role of coal be in energy economy? In what areas should the development of renewable energy sources be promoted? What should the rate of integration in the national electric energy market with the EU market be and, as a consequence, what should the European compromise for the energy sector be? [62].

Over the last five years, the problems of the energy economy have gained importance for the public. At the same time, they are a constant and essential aspect in the work of the EU summit meetings. The research problem discussed is important from the point of view of sustainable development, environmental protection and economic security of electricity consumers.

Actions aimed at the implementation of sustainable development result from the fact that, at present, it is universally acknowledged that the previous paths of socio-economic development and a recreation of previously grounded trends for economic growth disregarding broadly understood environmental, social and economic consequences should not be maintained in the future.

Sustainable development requires the application of prevention and, first of all, foresight, preferably in all areas of socio-economic life [63]. A form of prevention seems to be 
enacting seeing changes in the consumption of electricity and the energy carriers used to generate it.

Based on experience, it is possible to reduce greenhouse gas emissions in the EU. This results mainly from reducing the use of hard coal and lignite in electricity production (in favor of increasing the importance of renewable energy). The effects of the 2005-2015 period showed that greenhouse gas emissions fell below the target set for 2020 [5].

Author Contributions: Conceptualization, P.S., J.H., J.L. and A.R.; methodology, P.S., J.L.; software, P.S., J.L.; validation P.S., J.H., J.L. and A.R.; formal analysis, P.S., J.H., J.L. and A.R., investigation, P.S., J.H., J.L. and A.R., resources, P.S., J.H., J.L. and A.R., data curation, P.S., J.H., J.L. and A.R.; writing—original draft preparation, P.S., J.H., J.L. and A.R., writing-review and editing, P.S., J.H., J.L. and A.R.; visualization, P.S., J.H. and R.A; supervision, P.S., J.H., J.L. and A.R.; project administration, P.S.; funding acquisition, P.S., J.H. and J.L. All authors have read and agreed to the published version of the manuscript.

Funding: This research was financed from resources of the Faculty of Economics Poznań University of Life Sciences.

Institutional Review Board Statement: Not applicable.

Informed Consent Statement: Not applicable.

Data Availability Statement: Not applicable.

Conflicts of Interest: Not applicable.

\section{References}

1. Abolhosseini, S.; Heszmati, A.; Altmann, J. Review of Renewable Energy Supply and Energy Efficiency Technologies; Discussion Paper Series; IZA: Bonn, Germany, 2014; Volume 8145, pp. 1-35.

2. Ritchie, H.; Roser, M.; Fossil Fuels. Our World Data. 2017. Available online: https:/ / ourworldindata.org/fossil-fuels (accessed on 10 November 2021).

3. EPA. Greenhouse Gas Emissions. Global Emissions by Economic Sector, Washington: United States Environmental Protection Agency. Available online: https: / / www.epa.gov/ (accessed on 10 November 2021).

4. Emisje Gazów Cieplarnianych w Unii Europejskiej, Dostęp. Available online: https://www.europarl.europa.eu/news/pl/headlines/ society/20180301STO98928/infografika-emisje-gazow-cieplarnianych-w-unii-europejskiej (accessed on 10 September 2021).

5. Energy and Climate Change. Signals 2017-Shaping the Future of Energy in Europe, No 142; ECC: Copenhagen, Denmark, 2017.

6. Altawell, N.; Milne, J.; Seowou, P.; Sykes, L. Rural Electrification: Optimizing Economics, Planning and Policy in an Era of Climate Change and Energy Transition, 1st ed.; Academic Press: Cambridge, MA, USA, 2020; pp. 19-38.

7. Bałamut, A. Polish energy security police in the years 2000-2015. (Polityka bezpieczeństwa energetycznego polski w latach 2000-2015). Teoria Prakt. 2017, 29, 49-64.

8. Energy Production and Imports: Eurostat 2020. Available online: https://ec.europa.eu/eurostat/statistics-explained/index.php? title=Energy_production_and_imports /pl (accessed on 25 March 2021).

9. Yergin, D. Ensuring Energy Security. In Foregin Affairs; Council on Foreign Relations: New York, NY, USA, 2006; Volume 85, pp. 69-82.

10. European Commission. Twenty Five Years of the Common Market in Coal 1953-1978; Office for Official Publications of the European Communities: Luxemburg, 1977; pp. 143-144.

11. Vallebona, M. The Genesis and Modification of the Common EU Energy Policy. Econ. Political Thought 2015, 1, 92-112.

12. Grycan, W.; Wnukowska, B.; Wróblewski, Z. Modelling of electric energy conditions of a region. Electrotech. Rev. 2014, 90, 230-233.

13. Trubalska, J. Towards the energy union. A new concept of energy security in the EU. Zesz. Naukowe Inst. Gospod. Surow. Miner. Energia Pol. Akad. Nauk 2017, 97, 21-32.

14. European Commission. Final Communication from The Commission Clean Energy for All Europeans; European Commission: Brussels, Belgium, 2019.

15. SWD. Underlying Results of the Impact Assessment for the Amendment of the Energy Efficiency Directive; SWD: Brussels, Belgium, 2016; p. 405.

16. SWD. Impact Assessment for the Recast of the Renewables Directive; SWD: Brussels, Belgium, 2016; p. 418.

17. European Commission. European Energy and Transport Trends to 2030; European Commission: Brussels, Belgium, 2010.

18. Poland's Energy Policy until 2040. Ministry of Climate and Environment. Available online: https://www.gov.pl/web/klimat/ polityka-energetyczna-polski (accessed on 26 March 2021).

19. Trzepacz, P. Genesis and Essence of the Sustainable Development Concept. In Sustainable Development-Global Challenges; Instytut Geografii i Gospodarki Przestrzennej UJ: Cracow, Poland, 2012; pp. 11-37. 
20. Sustainable Development and Its New Challenges. Available online: https:/ / www.ceeol.com/search/article-detail?id=747496 (accessed on 15 September 2021).

21. Rokicka, E.; Woźniak, W. Towards Sustainable Development. Concepts, Interpretations, Contexts; University of Lodz: Łódź, Poland, 2016.

22. Latoszek, E. The Concept of Sustainable Development in Theory and Practice ONZ 25-65. In Sustainable Development and Global Public Goods in Theory and Practice of International Organisations; Latoszek, E., Proczek, M., Krukowska, M., Eds.; Elipsa: Warszawa, Poland, 2016; pp. 25-64.

23. European Commission. Final Communication from The Commission Clean Energy for All Europeans; European Commission: Brussels, Belgium, 2016.

24. Wróbel, P. Analyzes and dialogue. In Small Steps to Big Changes: Impact of the Clean Energy for All Europeans Package on Energy; Energy Forum: Warszawa, Poland, 2019; p. 9, [Forum energii. Analizy i dialog. Małymi krokami do wielkich zmian Wpływ pakietu „Czysta energia dla wszystkich Europejczyków” na energetykę, wrzesień 2019, p. 9].

25. Rising Energy Consumption Slows EU Progress on Renewables and Energy Efficiency Targets. Available online: https://www. eea.europa.eu/highlights/rising-energy-consumption-slows-eu (accessed on 25 March 2021).

26. The European Green Deal, Communication from The Commission COM (2019) 640 Final, Brussels, 11.12.2019. Available online: https:/ / eur-lex.europa.eu/legal-content/EN/TXT/?uri=COM\%3A2019\%3A640\%3AFIN (accessed on 14 September 2021).

27. Szpak, K. The EU Climate Policy for 2050. In Climate Policy and Its Implementation in the First Half of the 21st Century; Gajewski, G., Paprocki, W., Eds.; Centrum Myśli Strategicznych: Gdansk, Poland, 2020; pp. 34-53.

28. Mrowiec, M. Economic Aspects of the Climate Policy. In Climate Policy and Its Implementation in the First Half of the 21st Century; Gajewski, G., Paprocki, W., Eds.; Centrum Myśli Strategicznych: Gdansk, Poland, 2020; pp. 203-217.

29. Ceglarz, A.; Polish Energy Policy. Climate Change, Energy and the Environment. Friedrich-Ebert-Stiftung. 2020. Available online: http:/ / library.fes.de/pdf-files/bueros/warschau/17099.pdf (accessed on 14 September 2021).

30. The Just Transition Mechanism: Making Sure No One is Left Behind. Available online: https://ec.europa.eu/info/strategy/ priorities-2019--2024/european-green-deal/actions-being-taken-eu/just-transition-mechanism_en (accessed on 10 September 2021).

31. Jonker, J.; Krukowska, M. Transformation Towards Sustainable Development. In Management and Business Administration; Central Europe, 4/2012 (117); Akademia Leona Koźmińskiego: Warsaw, Poland, 2012; pp. 92-106. ISSN 2084-3356.

32. Pearce, D.; Markandya, A.; Barbier, E.B. Blueprint for a Green Economy; Earthscan: London, UK, 1989.

33. UNEP. Towards a Green Economy: Setting the Stage for a Green Economy Transition. 2011. Available online: http://www.unep. org/greeneconomy (accessed on 13 August 2011).

34. Regional Just Transformation Plans Will Promote Use of EU Funds. Available online: https://www.gov.pl/web/funduszeregiony/terytorialne-plany-sprawiedliwej-transformacji-pomoga-korzystac-z-funduszy-unijnych (accessed on 25 March 2021).

35. European Commission. A Clean Planet for All: A European Strategic Long-Term Vision for a Prosperous, Modern, Competitive and Climate Neutral Economy; European Commission: Brussels, Belgium, 2018.

36. Report from the Commission to The European Parliament, The Council, The European Economic and Social Committee and The Committee of The Regions Renewable Energy Progress Report. Available online: https:/ / eur-lex.europa.eu/legal-content/EN/ TXT/?uri=CELEX\%3A52017DC0057 (accessed on 30 September 2021).

37. Report from the Commission to The European Parliament, The Council, The European Economic and Social Committee and The Committee of The Regions Renewable Energy Progress Report. Com/2020/952 Final. Available online: https://ec.europa.eu/ energy /sites/ener/files/renewable_energy_progress_report_com_2020_952.pdf (accessed on 30 September 2021).

38. Middlemiss, L.; Ambrosio-Albalá, P.; Ross, N.E.; Gilbertson, G.; Hargreaves, T.; Mullen, C.; Ryan, T.; Snell, C.; Tod, A. Energy poverty and social relations: A capabilities approach. Energy Res. Soc. Sci. 2019, 55, 227-235. [CrossRef]

39. Energy Prices and Costs in Europe. COM 951 Final. 2020. Available online: https://eur-lex.europa.eu/legal-content/PL/TXT/ PDF/?uri=CELEX:52020DC0951\&from=EN (accessed on 30 September 2021).

40. Electricity in Households by Recipient's Location, Local Data Bank of the Central Statistical Office. Available online: https: / /bdl.stat.gov.pl/BDL/metadane/cechy/1880 (accessed on 20 March 2021)(Energia elektryczna w gospodarstwach domowych wg lokalizacji odbiorcy, Bank Danych Lokalnych GUS, dostęp: 20 marzec 2021 r.).

41. Wysocki, F.; Lira, J. Descriptive Statistics. Wydawnictwo Akademii Rolniczej Im; Augusta Cieszkowskiego: Warszawa, Poland, 2003.

42. Arığlu Akan, M.; Selam, A.; Oktay Fırat, S.; Er Kara, M.; Özel, S. A Comparative Analysis of Renewable Energy Use and Policies: Global and Turkish Perspectives. Sustainability 2015, 7, 16379-16407. [CrossRef]

43. Gielen, D.; Boshell, F.; Saygin, D.; Bazilian, M.D.; Wagner, N.; Gorini, R. The role of renewable energy in the global energy transformation. Energy Strategy Rev. 2019, 24, 38-50. [CrossRef]

44. Report 2004 National Electricity Network—Compilation of Quantitative Data. Available online: www.pse.pl (accessed on 1 March 2021). (Raport 2004 Krajowa Sieć Elektroenergetyczna-zestawienie danych ilościowych. www.pse.pl-dostęp: 1 marca 2021 r.).

45. Report 2019 National Electricity Network-Compilation of Quantitative Data. Available online: www.pse.pl (accessed on 1 March 2021). (Raport 2004 Krajowa Sieć Elektroenergetyczna-zestawienie danych ilościowych. www.pse.pl-dostęp: 01.03.2021 r).

46. Statistical Analyses, Rural Areas in Poland in 2018, Statistics Poland, Warsaw, Olsztyn 2020. Available online: https:/ /stat.gov.pl/ obszary-tematyczne/rolnictwo-lesnictwo/rolnictwo/obszary-wiejskie-w-polsce-w-2018-roku,2,4.html (accessed on 30 August 2021). 
47. Stanny, M.; Rosner, A.; Komorowski, Ł. Monitoring of Rural Development. Stage III. Socio-Economic Structures, Their Spatial Diversification and Dynamics (Monitoring of Rural Development. Stage III. Socio-Economic Structures, Their Spatial Differentiation and Dynamics); EFRWP, IRWiR PAN: Warsaw, Poland, 2018; (Monitoring Rozwoju Obszarów Wiejskich. Etap III. Struktury Społeczno-Gospodarcze, Ich Przestrzenne Zróżnicowanie i Dynamika (Monitorowanie rozwoju wsi. Etap III. Struktury społecznogospodarcze, ich zróżnicowanie przestrzenne i dynamika) EFRWP, IRWiR PAN: Warszawa, Polska, 2018.

48. Wójcicki, Z. Agricultural production energy consumption based on research. Probl. Agric. Eng. 2015, 4, 31-41, (Energochłonność produkcji rolniczej na podstawie badań. Problemy Inżynierii Rolniczej. Z. 4(90) s. 31-41).

49. Jedlińska, K.; Olkuski, T. The decision-making process in the EU in the field of energy policy. Energy Policy J. 2019, 22, 5-18. [CrossRef]

50. Altawell, N.; Milne, J.; Seowou, P.; Sykes, L. Rural Electrification: Optimizing Economics, Planning and Policy in an Era of Climate Change and Energy Transition; Academic Press: Cambridge, MA, USA, 2021; pp. 201-230.

51. Kaygusuz, K. Sustainable energy, environmental and agricultural policies in Turkey. Energy Convers. Manag. 2010, 51, 1075-1084. [CrossRef]

52. Marecki, J. Prospects for the development of the power industry in Poland until 2020. Electrotech. Review. 2002, 78, 210-214.

53. Jaczewski, M.; Marecki, J.; Sikora, W. Programme for Coal and Electrictiy Demand by 2020; Ekspertyza KPE PAN: Warszawa, Poland, 1999.

54. Standar, A.; Kozera, A.; Satoła, L. The Importance of Local Investments Co-Financed by the European Union in the Field of Renewable Energy Sources in Rural Areas of Poland. Energies 2021, 14, 450. [CrossRef]

55. Sutherlan, L.A.; Pete, S.; Zagata, L. Conceptualising multi-regime interactions: The role of the agriculture sector in renewable energy transitions. Res. Policy 2015, 44, 1543-1554. [CrossRef]

56. Popp, J.; Lakner, Z.; Harangi-Rákos, M.; Fári, M. The effect of bioenergy expansion: Food, energy, and environment. Renew. Sustain. Energy Rev. 2014, 32, 559-578.

57. Jasiulewicz, M. Production of energy from agribiomass in Poland in the background of selected countries of the European Union. Rocz. Naukowe SERiA 2015, 8, 94-99.

58. Owczuk, M.; Wardzińska, D.; Zamojska-Jaroszewicz, A.; Matuszewska, A. The use of biodegradable waste for the production of biogas as an alternative source of renewable energy. Stud. Ecol. Bioet. UKSW 2013, 11, 133-144.

59. Damyanova, S.; Beschkov, V. Biogas as a Source of Energy and Chemicals. Biorefinery Concepts, Energy and Products. In Biorefinery Concepts; IntechOpen: London, UK, 2020.

60. Nevzorova, T.; Kutcherov, V. Barriers to the wider implementation of biogas as a source of energy: A state-of-the-art review. Energy Strat. Rev. 2019, 26, 100414. [CrossRef]

61. Kamrat, W. Problems of Energy Sector Development in View of Increased Natural Gas Supply. Available online: https://www. cire.pl/ (accessed on 26 March 2021).

62. Maćkowiak-Pandera, J.; Rączka, J.; Bukowski, M. Polish Energy Sector at Megatrends; Forum Analiz Energetycznych: Warszawa, Poland, 2016.

63. Jeżowski, P. Sustainable Development and Its New Challenges. Available online: https://ssl-kolegia.sgh.waw.pl/pl/KES/ czasopisma/kwartalnik/archiwum/Documents/PJezowski10a.pdf (accessed on 30 November 2021). 